\title{
An Economics Perspective Ten Years After the NAB Case
}

\section{Brooks B. Hull}

The U.S. Justice Department filed suit against the National Association of Broadcasters (NAB) in 1979, charging that the NAB Television Code damaged commerce by restricting the supply and raising the price of television advertising. Federal District Court Judge Harold Greene issued a consent decree in 1982, under which provisions the NAB eliminated Television Code sections regulating television commercials.

The NAB case is an interesting and important subject for study, For one, the NAB case shares characteristics with the historic antitrust case against AT\&T. Both cases were adjudicated by Judge Greene, who took an active stand against the activities of a pervasive communications medium. Further, both cases were settled by a consent decree whose impact on consumers was uncertain at the time of the case and remains in dispute.

The nature of the television product also makes studying the antitrust case interesting. Commonly in antitrust cases, colluding firms are accused of conspiring to restrict the output or raise the price buyers face. The usual welfare economics argument shows how society fails to exploit all potential gains from trade because total output is less than is socially optimal. In the case of television, however, broadcasters provide a public good to viewers without charging a direct fee and earn revenue by selling commercial time to advertisers. The connection between restrictions on commercials and consumer welfare is not so obvious as in the usual antitrust cases. Further, although they would not want broadcasters to collude and raise prices for commercial time, advertisers are surely sensitive to potential dilution of their messages 
because of excessive commercials on programs and so might favor some limits on commercials.

Congress is considering restricting the amount of commercial material during children's programs ("Children's Television," 1988). These restrictions, supported by organizations like Action for Children's Television, are exactly the same as those eliminated from the NABCode (NAB, 1981, XIV, 2, c). The effect of such regulation on stations and viewers can be evaluated fairly only after analyzing the effects of the NAB's Television Code.

This article examines the NAB's Television Code and its suspension from both a theoretical and an empirical viewpoint, concluding that the consent decree was at best unnecessary and at worst ill advised. The next section provides some background on the NAB, the Television Code, and the antitrust case. The third section presents statistical evidence that the code did not directly significantly increase television station profit. The fourth section reviews reasons why stations would adopt a code and considers some welfare implications of a successful code.

\section{The NAB Code}

The National Association of Broadcasters is the primary industry trade association. The NAB provides technical assistance, managerial consulting, and industry lobbying. Before Judge Greene's decision, the $\mathrm{NAB}$ issued voluntary radio and television codes.

The Television Code, administered by the NAB Code Authority, contained both ethical provisions and advertising restrictions. The ethical provisions prohibited advertisements for hard liquor, guns, and some other products, and provided standards for a variety of activities including payments by advertisers for displaying products within programs.

The code's advertising rules set maximum limits for minutes of commercials, number of commercials, and number of commercial interruptions. Separate limits applied to prime-time programs, to children's programs, to some other types of programs, and for network affiliates. Multiple product announcements were prohibited (NAB, 1981). The Code Authority monitored and encouraged subscriber compliance and had the power to expel from the code stations violating its standards. 
The stated purpose of the code was "to maintain the highest possible programming and advertising standards" (NAB, Code Authority, 1980). This may have been a reasonable goal for an industry hoping to maintain the good will of a vast viewing and voting audience. The code also surely was designed to counter lobbying efforts by consumer groups and so forestall more restrictive and less flexible regulations imposed by the FCC. To quote the NAB: "The greater the number of Code subscribers who support voluntary self-regulation, the more effective the industry and individual broadcasters will be in countering unnecessary and overly restrictive government controls" (NAB, Broadcasters Working Together, n.d.). In this case, a successful code would benefit stations indirectly to the extent that actual code standards were less restrictive than potential FCC standards. Other possible indirect benefits of the code are discussed later in this article.

The code might also have been intended to increase station profit directly. This possible (and unstated) purpose of the code would be to restrict output of advertising in the same way that colluding firms restrict output in an effort to increase industry profit. Media researchers like Owen, Beebe, and Manning (1974, pp. 101-111) acknowledge this potential purpose of the code and this possibility motivated the Justice Department suit.

Reflecting trade association case law (Asch, 1983), Judge Greene ruled that code restrictions on multiple product announcements were illegal per se. Greene chose to employ a rule of reason and evaluate the actual harm caused by the other provisions of the code. Fearing an adverse decision, the NAB eventually accepted a consent decree suspending code commercial limits, leaving unanswered the question of the effect of the code's commercial limits.

Data measuring the code's effect on television advertisers are unavailable. Also unavailable are data measuring changes in the actual number of commercials shown by stations or included in network programs. However, even if these data were available and showed that the code reduced the number of commercials, the code might not have been intended to increase profit directly in a manner consistent with the sort of collusion addressed in the antitrust case.

Critical evidence of the NAB's motivation for creating and enforcing the code is whether the code directly increased broadcaster profit. The primary objective of this paper is to evaluate implications derived if the code was indeed successful as a direct collusive device. 


\section{Results}

If the primary purpose of the television code was to restrict the number of commercials in an effort to directly increase member station and network profit, the effects of such restrictions should be observable. Three of these effects are considered below, each in the form of an implication and a statistical test:

Implication 1: Other factors held constant, the selling price of television stations should be higher in markets with a larger share of audience viewing code subscriber stations.

Like any other valuable asset, the price of a television station is the present value of current and anticipated profit: the difference between revenue and cost over time. A station's price reflects true economic profit, rather than accounting profit, and incorporates risk. The price is an inaccurate measure if markets for capital assets are inefficient and biased in one direction. In studying the television industry, Levin $(1964,1975)$ uses station sale price. Fournier and Martin (1983), Boyer and Wirth (1981), and Park, Johnson, and Fishman (1976) use station accounting data. FCC Network Inquiry Special Staff (1980) uses both accounting data and station sale price. Besen (1976) and Wirth and Wollert (1984) use commercial time prices. None of these authors include the $\mathrm{NAB}$ or its code in their models.

Station revenue comes from sale of commercial time on programs and, for some network stations, payments from networks for showing network programs and commercials. The most important determinant of station revenue is audience size. The price a station charges advertisers is directly related to the number of program viewers. Advertisers plan budgets based on the number of viewers exposed to a commercial and commercial contracts can contain provisions guaranteeing minimum audience size.

Audience size, in turn, is a function of the population in an area, the nature of competing programming, the presence of competition from cable systems, the station's programming, and characteristics of the station's signal.

Station cost includes the largely fixed cost of equipment and transmission and the production costs for local programming. Stations assigned to UHF channels must employ transmitting equipment that is 
more expensive to operate andthat produces a poorer signal with less range than VHF channels. Stations also buy some programming in the syndication market. Independent stations, in particular, must rely on less attractive syndicated programs.

To directly increase station profit, a sufficient proportion of stations must reduce their quantity of commercials shown. If successful, the price of commercials and total revenue for all stations increases. Also require is an inelastic demand for commericals by advertisers, without which direct collusion serves no purpose. This assumption is common (see, for example, Koford, 1984). The higher the proportion of code subscribers, the higher will be profit for all stations in the market.

Table 1 summarizes OLS regression results, the dependent variable being the prices of 96 U.S. commercial television stations sold between January 1976 and the code's suspension in March 1982. Prices are adjusted for different months of sale by the geometric mean annual Moody Aaa corporate bond yield. This adjustment should result in a measure of the station's true economic value by removing the impact of inflation and reflecting changes in the value of competing assets. Results are similar when station value is adjusted only for inflation.

TABLE 1

REGRESSION RESULTS WITH STATION SALE PRICE Constant Audience Codeshare Single $\overline{\mathbf{R}}^{2}$

Equation 1

1.51

(0.726)

$0.186^{* *}$

$-0.035$

0.153

$(-1.410)$

(0.055)

0.645

Equation 2

1.56

$0.186^{* *}$

$-0.35$

$-\cdot-$

0.645

(0.799)

(12.88)

$(-1.46)$

Equation 3

$-0.827$

$(-0.770)$

$0.181^{* *}$

(12.82)

* indicates significant at one percent. $n=96$.

Student's $t$ values are in parentheses. 
The variable AUDIENCE is the number of households in the A.C. Nielsen designated market area viewing the station from 9:00 a.m. to midnight. SINGLE is a dummy variable set to one for stations in single station markets. CODESHARE is the proportion of television households in the market area viewing code subscriber station programs. Code membership is recorded six months after the sale to allow time for adjustments in buyer behavior. Unless otherwise stated, data are recorded at time of sale. Appropriate variables are adjusted to November 1979.

The regressions shown in Table 1 exclude population, number of competing stations, channel number, network affiliation, and other factors of which audience size is a function. Also excluded are factors affecting station cost, channel number being an example. The reason these variables are excluded is that audience size is an effective proxy incorporating these and other factors, data for some of which are unavailable. When other available variables are included with audience size, coefficients on these other variables are dominated by audience size and so are statistically insignificant. If audience size is omitted and the other variables included, the predictive value of the regression equation falls. In any case, the coefficients on the critical CODESHARE and SINGLE variables are unaffected by alternate model specifications. See Foster and Hull (1986) for a complete treatment.

The significant and positive coefficient on the AUDIENCE variable shows the importance of viewer households to station profitability. Possessing a monopoly television station gives no special advantage; the SINGLE variable coefficient is insignificant. The extent of television code subscription (CODESHARE) has no significant impact on station profit. If they are sufficiently more attractive to viewers, stations which conform to the code and reduce the quantity of commercials will have larger audiences, other things constant. This might imply a multicollinearity problem. The extent of the problem depends on the response of total market audience (not station audience) to a change in the quantity of commercials produced by a sufficient share of stations (the variable CODESHARE). Researchers like Koford (1984) assert that total audience tends to remain relatively constant.

The CODESHARE and SINGLE variables are omitted from the second and third equations without effect. Audience size influences station profit; a collusive code at the local level does not. 
Implication 2: A smaller proportion of stations in single station markets should be code subscribers than in markets with two or more stations, other things being equal.

If its objective is to directly increase station profit by reducing the quantity of commercials, the code is unnecessary in single station markets. Stations in single station markets are already monopolies and do not need the code to enforce appropriate monopoly behavior. Because the three major networks were code subscribers, network stations received network programs that conformed to code standards. However, stations have some ability to alter the quantity of commercials in network programming. Stations can substitute commercials for public service and other announcements in network programming. Stations need not and do not clear all programming provided by their network. Network stations can control the number of commercials during the substantial periods of time when networks are not providing programs. Thus network stations in single station markets need not conform to code standards and not all network stations are code subscribers. In November 1980, 72 percent of stations in multistation markets were code subscribers. By contrast, only 39 percent of stations in single station markets subscribed (Standard Rate and Data Service, 1980).

Although this result is consistent with a collusive code, stations in single station markets are fundamentally different from other stations. Thus, "other things" are not equal. In particular, stations in single station markets have fewer viewers than other stations. Let code membership be a dummy dependent variable. The independent variables are AUDIENCE and SINGLE (both defined above). As Table 2 shows, probit analysis yields a coefficient on AUDIENCE asymptotically significant at 1 percent but an insignificant coefficient on SINGLE. The model predicts fifty-eight percent of the CODE outcomes.

Stations in single station markets have fewer viewers than stations in multistation markets and stations with fewer viewers are less likely to subscribe to the code. If code subscription increases profit but stations with larger audiences are more likely to subscribe, a problem arises. The code causes and is a result of higher profit. Foster and Hull (1986) address this problem by employing a dummy endogenous 
variable model. The model yields results consistent with those reported here. Stations are choosing to become code members for reasons other than the potential for monopoly power. The key factor shown here is audience size. Audience size may be indicative of how smaller stations have less reason to support any public service or lobbying characteristics of the code. These other effects of the code are discussed later.

\section{TABLE 2}

\section{PROBIT RESULTS WITH CODE MEMBERSHIP}

$\begin{array}{cccc} & \text { Constant } & \text { Audience } & \text { Single } \\ \text { Equation 1 } & 0.303 & 0.015^{* *} & -0.007 \\ & (0.441) & (3.22) & (-0.013)\end{array}$

**indicates asymptotically significant at one percent. $n=96$.

Figures in parenthesis are the ratios of the coefficient and the asymptotic standard error, distributed normally for large samples.

Implication 3: The rates of return on television broadcast industry stocks should fall when code enforcement ends.

Returns on common stock in part reflect expectations about firm performance. If the television code significantly increased station profits, important events in the antitrust case should have reduced broadcasting company stock returns. Importantly, this measure should detect successful code-enforced commercial restrictions among the networks and in regional advertising markets in addition to the local markets analyzed in the previous implications.

Stock prices will not indicate the value of the code if stock buyers expect stations to collude tacitly after the code is discontinued. In 1983, Alberto-Culver did bring suit against the NAB, one network, and several television station group owners claiming that these organizations were continuing to refuse multiple-productannouncementsdespite the consent decree. Alberto-Culver did not accuse plaintiffs of tacit collusion and excluded from the suit the other two networks and group owners (representing the majority of stations) that did not maintain the restriction (Broadcasting, November 21, 1983, pp. 25-26). Tacit collusion seems not to have occurred. 
Of course, stock returns are influenced by factors other than anticipated firm profits. To deal with these complications and to test the significance of changes in stock returns, researchers have developed a number of statistical techniques based on capital asset pricing models. Schwert (1981) reviews and updates these models. Binder (1985) also reviews the literature and makes some sophisticated additions.

The basic model assumes that returns on a given stock $R_{f t}$ are a linear function of returns on the market $R_{m t}$ and some random error:

$$
R_{j t}=\alpha_{j}+\beta_{j} R_{m t}+e_{j t}
$$

Market returns also contain a random element. The expected value of errors for a given firm is assumed to be zero. For each firm, errors are assumed to be uncorrelated and have constant variance.

If an important event like an antitrust case is expected to change the returns on particular stocks, actual returns will deviate from those generated by the previous underlying function. The statistical technique involves estimating the underlying function over a base period well before the important event and using these parameters to estimate returns during a test period including the event. If the event affects firm profitability, actual returns minus estimated returns (abnormal returns) during the test period will differ significantly from zero.

The daily returns including dividends on the common stocks of nine major broadcasting corporations are compiled from files maintained by the Center for Research in Securities Prices. The market return is the value-weighted stock return including dividends of all stocks on the New York Stock Exchange and is taken from the same source. The chosen companies are broadcasting firms or networks that own more than one television station, that are traded on the New York Stock Exchange, and for which complete data are available for the relevant periods. These firms were American Broadcasting Companies, CBS Inc., Capital Cities Communications, Cox Communications, Gannett, Liberty Corp., Metromedia, Storer, and Taft Broadcasting. Firms are excluded if they are a subsidiary of a non-broadcasting firm. $\mathrm{NBC}$, for example, is owned by the RCA Corporation.

Although the included firms often own other communications assets like cable television systems, the television broadcasting assets represent a substantial enough share of earnings that the model should 
detect the impact of the antitrust case. The companies own television stations in the largest markets and stations representing smaller markets in all regions of the United States. As an aside, several of the firms now own more non-television assets than during the period of interest here.

The particular statistical test employed here follows Linn and McConnell (1983). Daily stock returns and market returns for the period January 3, 1977, to January 3, 1978, are used to calculate nine sets of OLS parameters. These parameters in turn are used to estimate nine sets of daily returns for the test period. The test period starts on March 10,1982 , when the NAB suspended enforcement of the code, and ends on July 30,1982, two weeks after the proposed consent decree was filed.

Actual returns for the test period are subtracted from estimated returns to determine abnormal returns. If the code enforced collusive restrictions, the antitrust case will generate negative abnormal returns. Average abnormal returns are calculated for each stock and added to average abnormal returns for the other stocks. The result is divided by the expected standard deviation of abnormal returns. The resulting statistic is normally distributed with mean zero for large samples.

The cumulative abnormal average return (CAR) for the portfolio of nine broadcasting stocks is 0.457 . The expected standard deviation $\mathrm{S}(\mathrm{AR})$ for the portfolio is 0.335 . The resulting test statistic, $\mathrm{Z}=\mathrm{CAR} /$ $\mathrm{S}(\mathrm{AR})=1.37$, is not significantly different from zero and shows positive rather than negative excess returns. The returns on a portfolio of broadcasting stocks were not significantly adversely affected by important events in the antitrust case against the television code.

The equations deriving the $Z$ statistic testing the significance of cumulative average excess returns to broadcasting stocks follow Linn and McConnell (1983) in turn applying techniques in Fama (1976), Brown and Warner (1980), and DeGroot (1975). The statistic tests the null hypothesis that the cumulative average excess returns are significantly different from zero. The statistic has an asymptotically normal distribution with mean zero and standard deviation one. 
The $\mathrm{Z}$ statistic is calculated as the following:

$Z=C A R / S(A R)$,

$\mathrm{CAR}=(1 / \mathrm{N}) \sum_{\mathrm{j}=1}^{\mathrm{N}} \mathrm{CAR}_{\mathrm{j}}, \quad \mathrm{CAR}_{\mathrm{j}}=\left(1 / \mathrm{Q}^{1 / 2}\right) \sum_{\mathrm{t}=1}^{\mathrm{Q}}\left[\mathrm{AR}_{\mathrm{j}} / \mathrm{S}_{\mathrm{t}}\left(\mathrm{AR}_{\mathrm{j}}\right)\right]$,

$A R_{j t}=R_{f t}-\hat{R}_{j t}=R_{j t}-\left(\hat{\alpha}_{j}+\hat{\beta}_{j} R_{m t}\right)$

$S_{t}\left(A R_{j}\right)=\left\{S j 2\left[1+1 / T+\left(R_{m t}-R_{m}\right)^{2} / \sum_{k=1}^{T}\left(R_{m k}-R_{m}{ }^{2}\right]\right\}^{1 / 2}\right.$,

$\mathrm{S}(\mathrm{AR})=[\mathrm{T}-2 / \mathrm{N}(\mathrm{T}-4)]^{1 / 2}$

$\mathrm{N}=$ number of firms, in this case nine

$Q=$ number of trading days in test period, in this case 100

$j=a$ firm

$R_{f t}=$ observed daily returns on firm j's stock

$R_{n t}=$ observed daily returns on the market

$\wedge=$ estimated parameter

$S j 2=$ variance of residuals from OLS regression for the base period or firm $j$

$R_{m}=$ average daily return on the market during the base period

$\mathrm{T}=$ number of trading days on the base period, in this case 253 .

\section{The Purpose of the Code}

The evidence presented here strongly suggests that the NAB's Television Code failed if its objective was to increase profit directly as would occur under ordinary collusion. In addition, code membership in single versus multiple station markets appears to have been motivated by factors other than collusive profit maximization.

These results are not surprising. Code subscription was voluntary and violation of code provisions was at worst (and rarely) punished by prohibiting a station from displaying its code membership medallion on station advertising or on the air. Commonly, the Code Authority used only verbal persuasion to discourage misbehavior. That the code was widely ignored is confirmed by a 1963 FCC staff study that showed 
40 percent of stations exceeding code standards (Barnouw, 1970, pp. 250-51). Code enforcement and compliance were problematic.

The ability of the television code to increase station profit through collusive restrictions was also being eroded by changes in the broadcast industry. For one, cable television penetration was growing dramatically during the period of the antitrust case. Nationwide cable penetration increased from 19 percent to 46 percent in the years the NAB case was being argued and is now more than 51 percent ("By the Numbers," 1988).

Despite dissenting predictions by Noll, Peck, and McGowan (1973, pp. 151-182), cable has hurt major local stations. The benefit to a major local station from better signal reception is usually more than offset by the loss of viewers to the additional programs offered on cable (Webster, 1983). Smaller local stations gain viewers because of better signal reception, resulting in more competition for viewers and for advertising in the local market. An increase in the number of cable viewing options, some of which carry no commercials, also erodes the potential effectiveness of the code by increasing competition.

From the above, it is clear that code success was problematic. However, even an effective code does not assure monopoly profit. In addition, an effective code might have side effects that benefit viewers.

The argument is straightforward. The code only restricted the quantity of commercial material. Other programming dimensions were not controlled by the NAB and are in any case nearly impossible to measure meaningfully. In particular, stations have a competitive incentive to attract more viewers by increasing all of the dimensions of program quality, dimensions like signal strength, signal clarity, hours of operation, and characteristics of some programming (Fournier, 1985; Besen, 1976; Owen, et al., 1974, pp. 101-111). Any monopoly profits due to the code provided funds to support increases in quality, and competition pressures stations to use those funds.

The effects of such actions are obvious. Cost increases eventually outweigh increases in audience size and potential monopoly profit is dissipated. The difficulty faced by all cartels in monitoring and controlling output is exacerbated in the television industry by the multidimensional nature of programming.

Possible improvement in program quality is one (unintended) beneficial side effect of an effective restriction on the quantity of commercial material. Consumers also benefit more directly from successful restrictions. An effective code reduces the number of com- 
mercials. Although television commercials may contain valuable information, and some number of program interruptions certainly are desired by consumers, the typical consumer prefers fewer commercials on television. Research by Barnett (1966) and surveys by Steiner (1963) also supports this consumer attitude. Television viewer lobbying groups like Action for Children's Television recognized the potential disadvantages of the consent decree suspending code restrictions and even filed briefs opposing it.

Although it might have had the unintended effect of benefiting consumers through improved program quality and reduced commercial content, the statistical evidence suggests that the code did not achieve the collusive objective of raising station profit directly. Yet television stations voluntarily joined the code and the Code Authority took some pains to monitor and enforce code standards. What purpose, then, might the code have served?

As mentioned earlier in this article, one key function of the code surely was to counter lobbying efforts and the possibility of FCC regulation. Considering the statistical evidence against direct collusion, this might have been the code's sole purpose.

An additional objective of the code deserves mention, however. Code provisions that limit the number of commercials during a program help assure advertisers that subscriber stations avoid the overcommercialization that might dilute a given advertiser's message.

Information about the number of commercials a station shows is valuable to an advertiser, but costly for each advertiser to obtain independently about each station. In addition, each station has some incentive to misrepresent the actual number of commercials it shows and so earn extra revenue through overcommercialization. Although market forces provide some information and some protection against misbehavior, advertisers and honest stations would gain if a central organization monitored the quantity of commercial material and communicated this information. The Television Code may have served this purpose.

Note that in this case the code would not primarily restrict station behavior, but would advertise it. The Code Authority would not need any particular enforcement tools other than the ability to forbid noncomplying member stations from using the code seal.

Advertising industry publications like Spot Television Rates and Data note code subscription along with other extensive information about each station. These publications are widely used by advertisers. 
If it was included in advertiser publications, code membership information must have been valuable.

If the purpose of the code was to collusively restrict commercials and so directly raise station profit, stations hardly would have been inclined to advertise the restrictions to those who bought their product. Despite being made fully aware of the code and its member stations, advertisers did not bring suit against the Television Code (or the radio code) during the period before the Justice Department brought its case. For television, this represents the entire history of the industry. As mentioned, Alberto-Culver brought suit after the consent decree, although the suit opposed only multiple-product provisions of the code and did not accuse stations of collusion.

\section{Conclusion}

The main objective of this article is to present statistical evidence that the National Association of Broadcasters' Television Code did not significantly directly increase station profit. Television station sale prices were no higher in markets with a high proportion of code subscriberstations. Stations in single station markets were no less likely to subscribe to the code than stations with similar audience sizes in multiple-station markets. Finally, rates of return on broadcast firm and network stocks did not change when the antitrust case was settled. Regardless of its intent, the code was voluntary and could not control all programming dimensions. This information alone would have weakened the Justice Department case against the NAB had the case gone to trial under a rule of reason.

Although the code appears not to have been an effective collusive device, even an effective code would have beneficial (albeit unintended) side effects. Television viewers prefer fewer commercials and gain by any increased program quality resulting from competition on non-controlled program dimensions. Finally, the code largely was designed to prevent more onerous FCC regulation and probably provided valuable information to advertisers about station commercial policies.

Economic theory generally favors competitive markets but also recognizes that competitive markets may fail, especially in the case of products characterized by joint consumption. Television signals have this characteristic, and encouraging their optimal production may imply allowing some monopoly power. Had the antitrust case against 
the NAB gone to trial, Judge Greene would have evaluated the code based on its effect on the advertising market in particular and society in general. This article suggests that the appropriate decision in the case was in favor of the NAB Code. Either the code was ineffective and thus harmless or it benefited consumers and advertisers.

\section{References}

A.C. Nielsen and Co. Market Daypart Summaries, (various issues).

"Alberto-Culver sues over TV commercial guidelines," Broadcasting (November 21, 1983), pp. 25-26.

Asch, P. Industrial Organization and Antitrust Policy, rev. ed. New York: Wiley, 1983.

Barnett, H.J. "Discussion - Supply and Demand for Advertising Messages," American Economic Review 56(2):467-470 (1966).

Barnouw, Erik. A History of Broadcasting in the United States, Vol.2: The Image Empire. New York: Oxford University Press, 1970.

Besen, Stanley M. “The Value of Television Time," Southern Economic Journal 42:435-441 (1976).

Binder, J.J. "Measuring the Effects of Regulation with Stock Price Data," Rand Journal of Economics 16:167-183 (1985).

Boyer, K.D., and Michael O. Wirth. "The Economics of Regulation by Policy Directive: FCC Public-Interest Requirements," Quarterly Review of Economics and Business 21:77-96 (1981).

Broadcasting/Cablecasting Yearbook. Washington, D.C.: Broadcasting Publications, Inc., various years.

Brown, S. J., and J. B. Warner. "Measuring Security Price Performance," Journal of Financial Economics 8:205-258 (1980).

"By the Numbers," Broadcasting (April 25, 1988), p.14.

“Children's Television,” Broadcasting (May 2, 1988), p.14.

DeGroot, Morris H. Probability and Statistics. Reading, MA: Addison-Wesley, 1975.

Fama, E.F. Foundation of Finance. New York: Basic Books, 1976.

Foster, Carroll B., and Brooks Hull. "An OPECin Fantasyland: The NAB Television Code as Cartel," UM-Dearborn Economics Working Paper, no.41, 1986. 
Fournier, G. M. "Nonprice Competition and the Dissipation of Rents from Television Regulation," Southern Economic Journal 51:754-765 (1985).

Fournier, G.M., and D. Martin. "Does Government-Restricted Entry Produce Market Power? New Evidence from the Market for Television Advertising," Bell Journal of Economics 14:44-56 (1983).

Koford, K. "Was "Free" TV a Price Control that Increased Consumers' Welfare?" Quarterly Review of Economics and Business 24:67-77 (1984).

Levin, Harvey J. "Economic Effects of Broadcast Licensing," Journal of Political Economy 72:151-162 (1964).

Levin, Harvey J. "Franchise Values, Merit Programming and Policy Options in Television Broadcasting." In R. Caves and M. Roberts, Eds. Regulating the Product. Cambridge,MA: Ballanger Publishing Co, 1975.

Linn, S. C., and J. J. McConnell. "An Empirical Investigation of the Imapct of 'Antitakeover' Amendments on Common Stock Prices," Journal of Financial Economics 11:361-399 (1983).

National Association of Broadcasters. Broadcasters Working Together. Pamphlet, n.d.

National Association of Broadcasters. Code News. Washington, D.C.: National Association of Broadcasters, various issues.

National Association of Broadcasters. The Television Code 22nd ed. Washington, D.C.: National Association of Broadcasters, 1981.

National Association of Broadcasters, Code Authority. Functions and Procedures of the Code Offices Memorandum No. 29. Washington, D.C.: National Association of Broadcasters, May 1980.

Noll, Roger, Merton J. Peck, and John J. McGowan. Economic Aspects of Teleoision Regulation. Washington: Brookings Institute, 1973.

Owen, Bruce M., Jack H. Beebe, and Williard G. Manning, Jr. Television Economics. Lexington, MA: D.C. Heath \& Co, 1974.

Park, Rolla E., L. Johnson, and B. Fishman. Projecting the Growth of Television Broadcasting: Implications for Spectrum Use (Rand Report R-1841-FCC). Santa Monica, CA: Rand Corp, 1976.

Schwert, W. G. (1981). "Using Financial Data to Measure Effects of Regulation," Journal of Law and Economics_24:121-158 (1981)

Standard Rate and Data Service, Inc. Spot Television Rates and Data, 62. Skokie, IL: Standard Rate and Data Service, Inc., 1989. 
Wilcox, C., and W. G. Shepherd. Public Policies Toward Business (5th ed.). Homewood, IL: Irwin, 1975.

Wirth, Michael O., and James A. Wollert. "The Effect of Market Structure on Television News Pricing," Journal of Broadcasting and Electronic Media, 28:215-224 (1984). 